\title{
FIRST EVIDENCE OF EXISTENCE OF MICROPLASTICS IN STOMACH OF SOME COMMERCIAL FISHES IN THE LOWER GULF OF THAILAND
}

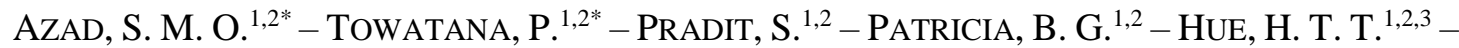 \\ JUALAONG, S. ${ }^{1,2,4}$
}

${ }^{1}$ Marine and Coastal Resources Institute (MACORIN), Prince of Songkla University (PSU), Hat Yai, Songkhla 90110, Thailand

${ }^{2}$ Coastal Oceanography and Climate Change Research Center (COCC), Prince of Songkla University (PSU), Hat Yai, Songkhla 90110, Thailand

${ }^{3}$ Central Institute for Natural Resources and Environmental Studies (CRES), Vietnam National University (VNU), Ha Noi, Vietnam

${ }^{4}$ Marine and Coastal Resources Research and Development Center Lower Gulf of Thailand,
Department of Marine and Coastal Resources, Songkhla 90100, Thailand

*Corresponding authors

S. M. O. Azad-e-mail: smoasiq664@gmail.com, phone: +66-63-547-7244

P. Towatana-e-mail: prawit.t@psu.ac.th, phone: +66-83-519-6002

(Received $5^{\text {th }}$ Aug 2018; accepted $8^{\text {th }}$ Oct 2018)

\begin{abstract}
Microplastics have turned into a key global environmental issue in the current decade because of their marine ubiquity, bioavailability and capability of carrying toxic chemicals. The study focuses, for the first time, on the existence of plastic debris in the stomach contents of some commercially important marine fishes caught from the lower Gulf of Thailand during August to November of 2017. Size and weight range of the samples were 8.5 to $37.1 \mathrm{~cm}$ and 8 to $133 \mathrm{~g}$. Results highlighted the ingestion of plastics in the $66.67 \%$ samples (110 out of 165 samples). The plastics ingested were microplastics $(79.52 \%)(<5 \mathrm{~mm})$, mesoplastics $(20.48 \%)(5-25 \mathrm{~mm})$. No macroplastic was found during this study since the study dealt with small fishes only. Transparent color plastics were the most dominant colors found in the stomach of fishes examined. Net fibres were the major types of plastics found during this study. There was no relationship found between size of plastics and different biological features of the investigated fishes. These initial findings signify an imperative phase in exploring ecotoxicological perspectives such as the existence and impact of plastic debris on the food chain; the probable effects related to the transmission of contaminants on human health etc.
\end{abstract}

Keywords: marine litter, microplastic, plastic ingestion, gut content, plastic pollution, anthropogenic debris, Gulf of Thailand

\section{Introduction}

Plastics are synthetic organic polymers, which are obtained from the poly-merisation of monomers extracted from oil or gas (Derraik, 2002; Rios et al., 2010; Thompson et al., 2009). In modern society, plastic has attained a crucial status, with widespread industrial, medicinal, municipal and commercial applications. Since mass production began in the 1940s, the annual plastic production has amplified from 1.5 million tonnes in the 1950s to 322 million tonnes in 2015 (PlasticsEurope, 2016). At present, plastic has been the fastest-growing urban waste and accounted for $60-80 \%$ of marine debris (Moore, 2008). Plastic waste has been assembled in the environment at a turbulent rate through inadvertent release and indiscriminate abandonment. Plastic has become a 
pervasive and dominant component of marine debris due to its lightweight, cumulative global production, durable nature and continuing inappropriate dumping (Derraik, 2002; Gregory, 2009; Moore, 2008; Thompson et al., 2009). Plastic is responsible for around $92 \%$ of all negative encounters between organisms and marine litter. The impacts of large plastic objects (i.e., macroplastic) on marine life were widely reported. It can cause various problems for fish and wildlife, such as ingestion, entanglement and death (Gall and Thompson, 2015). Above 660 marine species were known to be affected globally by plastic litter directly or indirectly (Dias and Lovejoy, 2012).

According to various studies, plastic litter is divided into three categories such as macroplastics, mesoplastics and microplastics (Browne, 2010; Fendall and Sewell, 2009). Plastic items break down into gradually smaller fragments due to oxidation, ultraviolet (UV) radiation and mechanical forces, which is below $5 \mathrm{~mm}$ in diameter and called microplastic (Barnes et al., 2009; Cole et al., 2011; Lippiatt et al., 2013). According to Lippiatt et al. (2013), size range of microplastics are $<5 \mathrm{~mm}$ to $0.1 \mu \mathrm{m}$ (Lippiatt et al., 2013). Microplastics are widely distributed, in deep sea sediments and surface water (Song et al., 2015; Woodall et al., 2014), from lakes to open sea water (Eriksen et al., 2014; Imhof et al., 2013), and in various marine organisms through the trophic levels (Boerger et al., 2010; De Witte et al., 2014; Murray and Cowie, 2011; Van Cauwenberghe and Janssen, 2014; Van Franeker et al., 2011). Numerous studies focused on the introduction of plastic and other anthropogenic debris in marine habitats and food web through digestion by diverse marine organisms, ranging from zooplankton to vertex predators (Fossi et al., 2014, 2012; Ivar Do Sul and Costa, 2014). In the stomach of Mediterranean organisms such as elasmobranches, turtles, teleosts and some invertibrates, plastic debris was also recorded (Deudero and Alomar, 2014; Lazar and Gračan, 2011). The effect of debris ingestion by marine wildlife was more explicit in those areas categorized by convergence currents, where anthropogenic debris was amassed (Moore et al., 2001).

From earlier studies, noteworthy amounts of plastics amassed into the marine environment and coastal ecosystems were primarily from Asian countries including Thailand which had moderately high economic growth rates (Jambeck et al., 2015). Plastic has also been acknowledged as one of crucial component in Municipal Solid Waste (MSW) composition of Thailand (Chiemchaisri et al., 2007; Kaosol, 2009). Therefore, land based plastic can be the core source of plastic pollution in coastal waters (Jambeck et al., 2015). However, at present, there are very few studies conducted on plastic pollution in Thailand. Particularly, no study was done on microplastic contamination in marine fish in lower southern Gulf of Thailand.

This study investigated, for the first time, the occurrence of plastic debris in the stomach content of various commercially important marine fishes together with the relationship between total plastic length and different biological features of fishes and details on plastic debris found in the stomach content of fishes.

\section{Materials and methods}

\section{Study site}

The study location (Sathing Phra District; 7²8'24'N, 100²6’18’E) was selected at Songkhla Province, the lower Gulf of Thailand (Fig. 1) to symbolize the coast with different anthropogenic activities. Neighboring districts of Sathing Phra are 
Singhanakhon of Songkhla Province, Pak Phayun of Phatthalung Province, Lrasae Sin and Ranot of Songkhla Province. To the east of Sathing Phra is the Gulf of Thailand. Sathing Phra is a coastal fishery community with commercial fishing and culture performance. However, the area is presently affected by adjacent fishing settlement and some tourism activities.

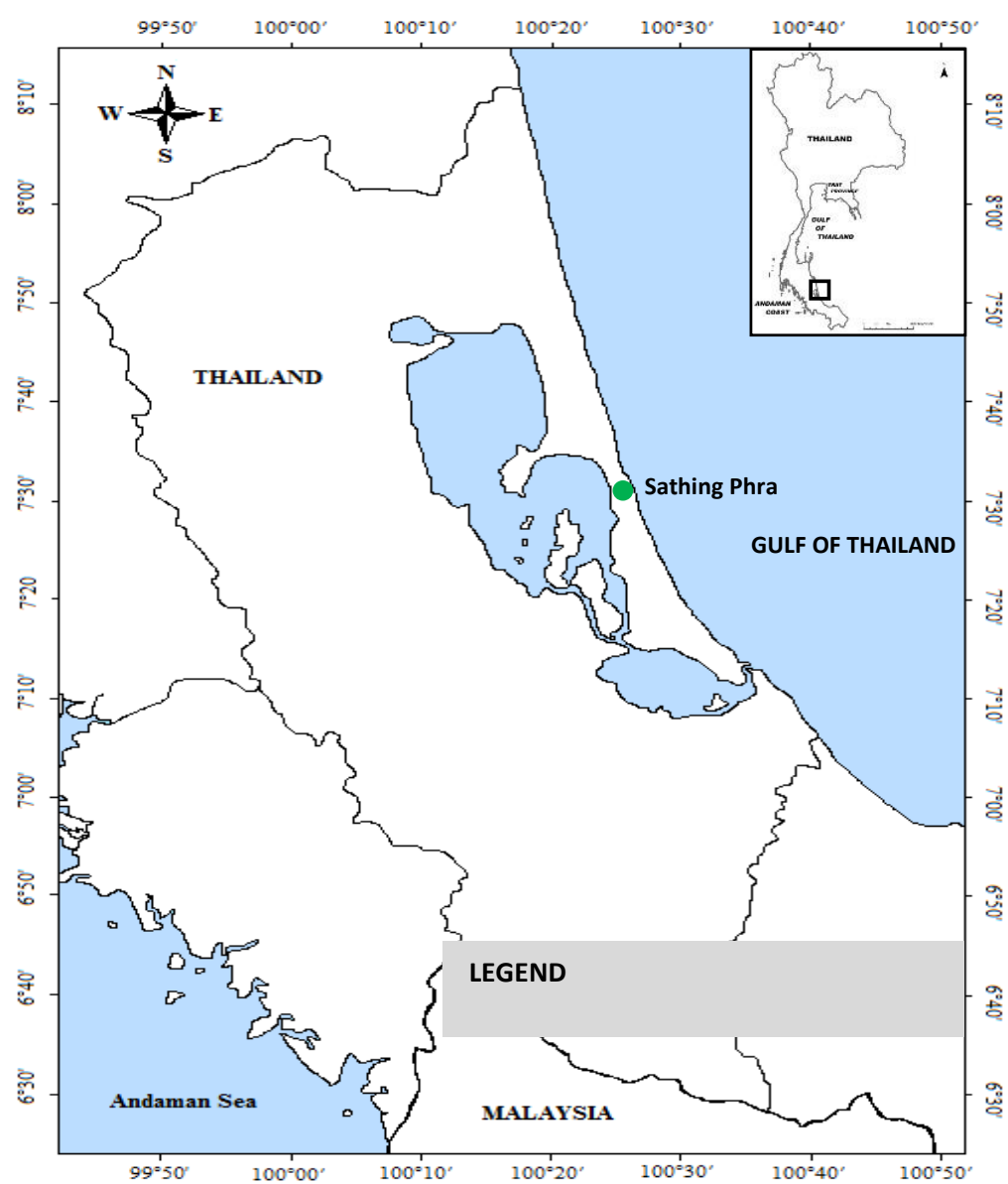

Figure 1. Map of the study site in Songkhla Province, the lower Gulf of Thailand

\section{Sampling and identification of fishes}

Fish samples were randomly collected from August to December of 2017 from the lower Gulf of Thailand. Fishes were caught by using different types of nets such as Shrimp net, Mackerel net and small traditional fishing boats were used to catch the fishes. Mackerel nets were hung vertically from a boat in the water with its bottom edge held down by weights and its top edge buoyed by floats. Particular information of the location and fishes were recorded. Then the fish samples were kept in an icebox with adequate ice and transported to the laboratory where they were immediately frozen and kept at $-20^{\circ} \mathrm{C}$ until further analysis.

Species of fish samples were primarily identified by the local fishermen and then their habitat, trophic level, sex and details about the species were assigned and verified according to the standard taxonomic keys of Talwar and Jhingran (1991); Froese and Pauly (2017); SEAFDEC (2014). Fishes were identified to species where possible and pictures were taken of individual fish for subsequent identification. 


\section{Analytical methods}

In the laboratory, each fish was defrosted subsequently and sampled fishes were thoroughly rinsed by filtered distilled water to remove sediments and impurities from the external veil. After thoroughly rinsing the samples, each specimen sample was measured (Total length, TL; Fork length, FL and mouth size - Fig. 2) and Weighed (Total weight, W).

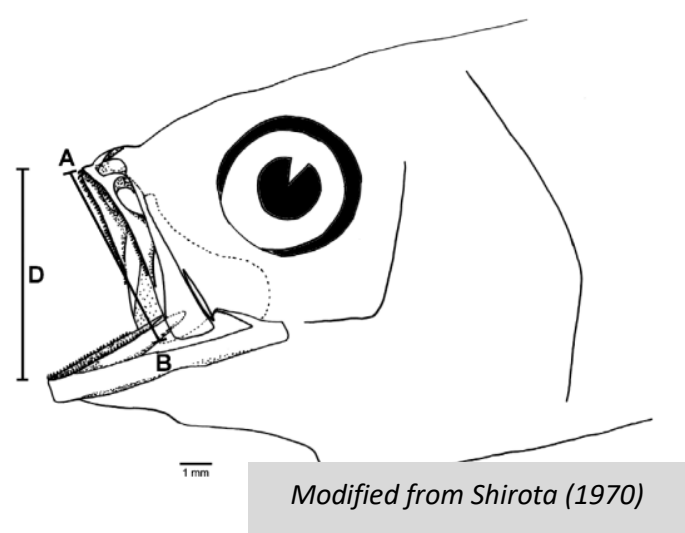

Figure 2. Measurement of mouth gape size of fish

In order to measure the mouth size of fish, the method proposed by Shirota (1970) was applied, which is as follows:

Mouth gap size of fish:

$$
\mathrm{D}=\sqrt{ } 2 A B
$$

where, $\mathrm{D}=$ Mouth gape size, $\mathrm{AB}=$ Measurement of upper-maxilla length

Equation 1 was performed based on the recommendations found in Shirota (1970). Considering that the conceptual size of the maximum width of food (in this case, plastic particles) corresponds to $50 \%$ of D (Shirota, 1970). Then subsequently, each fish was dissected from the upper part of the oesophagus to remove the stomach according to the methods published elsewhere (Claessens et al., 2013; Lusher et al., 2013; Rocha-Santos and Duarte, 2015). Stomach contents were then separately placed inside a petri dish. In laboratory, stomach contents were examined in order to identify plastic debris, which were then counted, grouped by color and measured (length) by the Stereo Zoom Microscope (OLYMPUS SZ2-ILST). To determine the length of each particle of debris, all photographed pieces were digitally measured using the software package ImageJ 1.4.3.6 (Public domain). The ingested plastics were categorized as microplastics $(<5 \mathrm{~mm})$, mesoplastics $(5-25 \mathrm{~mm})$ and macroplastics $(>25 \mathrm{~mm})$ following Galgani et al. (2013).

According to Equation 2, to figure the total magnification of an image, the power of the objective (1X, 2X, 3X, 4X) which were set according to the precision of the plastic debris were multiplied by the power of the eyepiece (10X).

Total magnification: 


\section{Preclusion of contamination}

Prominent maintenance was taken to preclude sample adulteration during dissection, extraction, sorting and visual identification. Our method includes numerous steps such as (i) Implement personal hygiene program, (ii) Use seperate equipments, (iii) Clean and sanitize all work surfaces etc. to avoid procedural contamination, crosscontamination and/or misidentification of natural debris (e.g., shells, algae, and coral) as anthropogenic debris. To obviate cross- contamination, all utensils and glassware were rinsed three times with distilled water between samples.

\section{Statistical analysis}

All data analysis was performed in Microsoft excel for mean, minimum and maximum. The frequency of plastic debris occurrence $(F \%)$ in these fish was estimated by the quantity of the individuals observed where plastics were present in the stomach contents. The R 3.2.0 (R Core Team, 2015) statistical software was used to analyze the data.

\section{Results}

Overall, 258 plastic fragments were recognized from the stomach content of 110 fishes $(66.67 \%)$ and in particular 15 demersal individual fishes $(50 \%), 51$ pelagic individual fishes (68.92\%) and 44 reef- associated individual fishes (72.13\%) (Table 2). Table 1 reports mean values and range of fork length, total length and weight of fishes together with the information on sex ratio and habitat of examined fishes.

Table 1. Mean values and range of fish lengths and weight for each fish species with their habitat

\begin{tabular}{|c|c|c|c|c|c|c|c|c|}
\hline \multirow{2}{*}{$\begin{array}{c}\text { Trophic } \\
\text { level }\end{array}$} & \multirow{2}{*}{ Fish species } & \multirow{2}{*}{$\begin{array}{l}\text { Sample } \\
\mathbf{n}(\mathbf{m}+\mathbf{f})\end{array}$} & \multicolumn{2}{|c|}{ Fork length $(\mathrm{cm})$} & \multicolumn{2}{|c|}{ Total length $(\mathrm{cm})$} & \multicolumn{2}{|c|}{ Weight (g) } \\
\hline & & & Mean \pm SD & Range & Mean \pm SD & Range & Mean \pm SD & Range \\
\hline \multirow{6}{*}{ 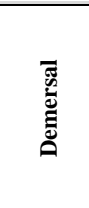 } & Alepes apercna (Grant, 1987) & $3(2+1)$ & $12.5 \pm 0.4$ & $13.0-12.2$ & $14.5 \pm 0.6$ & $15.2-14.0$ & $38.3 \pm 3.2$ & $42.0-36.0$ \\
\hline & Dasyatis zugei (Müller \& Henle, 1841) & $3(2+1)$ & - & - & $36.6 \pm 0.5$ & $37.1-36.2$ & $86.0 \pm 3.6$ & $89.0-82.0$ \\
\hline & Dendrophysa russellii (Cuvier, 1829) & $3(1+2)$ & - & - & $12.9 \pm 1.7$ & $14.0-11.0$ & $32.7 \pm 4.2$ & $36.0-28.0$ \\
\hline & Leiognathus berbis (Valenciennes, 1835) & $8(2+6)$ & $8.5 \pm 0.9$ & $9.8-7.5$ & $9.6 \pm 1.0$ & $10.9-8.5$ & $13.3 \pm 4.3$ & $20.0-8.0$ \\
\hline & Leiognathus fasciatus (Lacepède, 1803) & $3(2+1)$ & $8.0 \pm 0.2$ & $8.1-7.8$ & $9.5 \pm 0.1$ & $9.6-9.5$ & $13.3 \pm 1.2$ & $14.0-12.0$ \\
\hline & Leiognathus splendens (Cuvier, 1829) & $10(3+7)$ & $8.7 \pm 0.3$ & $9.3-8.2$ & $9.9 \pm 0.5$ & $11.0-9.3$ & $13.2 \pm 3.2$ & $19.0-8.0$ \\
\hline \multirow{11}{*}{ 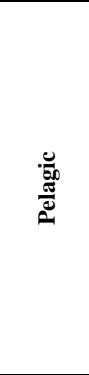 } & Alepes melanoptera (Swainson, 1839) & $8(3+5)$ & $15.4 \pm 0.8$ & $17.1-14.4$ & $17.2 \pm 0.8$ & $18.2-16.0$ & $57.1 \pm 8.5$ & $73.0-49.0$ \\
\hline & Alepes vari (Cuvier, 1833$)$ & $3(0+3)$ & $17.2 \pm 0.3$ & 17.4-16.9 & $19.0 \pm 0.8$ & $19.6-18.1$ & $83.7 \pm 4.0$ & $88.0-80.0$ \\
\hline & Anodontostoma chacunda (Hamilton, 1822) & $14(8+6)$ & $11.0 \pm 1.4$ & $13.2-9.3$ & $13.1 \pm 1.6$ & $16.0-11.1$ & $32.6 \pm 13.6$ & $59.0-17.0$ \\
\hline & Johnius borneensis (Bleeker, 1851) & $3(3+0)$ & - & - & $12.7 \pm 0.3$ & $12.9-12.4$ & $24.7 \pm 1.5$ & $26.0-23.0$ \\
\hline & Johnius carouna (Cuvier, 1830) & $20(9+11)$ & - & - & $16.1 \pm 3.1$ & $22.7-12.0$ & $53.9 \pm 29.4$ & $129.0-15.0$ \\
\hline & Opisthopterus tardoore (Cuvier, 1829) & $3(0+3)$ & $10.3 \pm 0.4$ & $10.7-10.0$ & $11.7 \pm 0.4$ & $12.1-11.4$ & $11.0 \pm 2.6$ & $14.0-9.0$ \\
\hline & Rastrelliger brachysoma (Bleeker, 1851) & $3(0+3)$ & $15.2 \pm 0.3$ & $15.5-14.9$ & $17.3 \pm 0.4$ & $17.6-16.9$ & $43.3 \pm 2.1$ & $45.0-41.0$ \\
\hline & Sardinella gibbosa (Bleeker, 1849) & $3(3+0)$ & $13.9 \pm 1.1$ & $14.6-12.6$ & $15.6 \pm 1.1$ & $16.3-14.3$ & $32.7 \pm 7.5$ & $37.0-24.0$ \\
\hline & Sardinella jussieu (Lacepède, 1803) & $8(4+4)$ & $10.8 \pm 0.6$ & $11.5-10.0$ & $12.7 \pm 0.7$ & $13.7-12.1$ & $22.5 \pm 4.3$ & $32.0-19.0$ \\
\hline & Scomberomorus commerson (Lacepède, 1800) & $4(1+3)$ & $21.1 \pm 3.7$ & 26.4-18.6 & $23.5 \pm 4.3$ & $29.8-20.5$ & $98.3 \pm 56.4$ & $182.0-61.0$ \\
\hline & Scomberomorus guttatus (Bloch \& Schneider, 1801) & $5(5+0)$ & $17.0 \pm 0.6$ & 17.9-16.3 & $19.9 \pm 0.8$ & $21.1-19.0$ & $52.4 \pm 6.1$ & $62.0-47.0$ \\
\hline \multirow{8}{*}{ 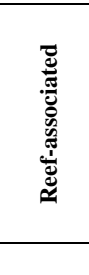 } & Alepes kleinii (Bloch, 1793) & $4(1+3)$ & $12.4 \pm 0.6$ & $12.8-11.5$ & $14.0 \pm 0.5$ & $14.3-13.3$ & $29.5 \pm 3.1$ & $32.0-25.0$ \\
\hline & Drepane longimana (Bloch \& Schneider, 1801) & $3(1+2)$ & - & - & $15.6 \pm 0.8$ & $16.3-14.7$ & $116.7 \pm 14.7$ & $133.0-105.0$ \\
\hline & Megalaspis cordyla (Linnaeus, 1758) & $29(25+4)$ & $16.3 \pm 1.1$ & $18.3-13.8$ & $18.0 \pm 1.4$ & $20.7-15.3$ & $53.7 \pm 12.3$ & $77.0-36.0$ \\
\hline & Sardinella albella (Valenciennes, 1847) & $14(6+8)$ & $12.5 \pm 1.2$ & $13.8-10.2$ & $14.2 \pm 1.3$ & $15.5-11.6$ & $30.9 \pm 7.4$ & $40.0-19.0$ \\
\hline & Scomberoides tala (Cuvier, 1832) & $3(1+2)$ & $16.2 \pm 1.5$ & $17.1-14.4$ & $18.0 \pm 2.4$ & $19.4-15.2$ & $51.0 \pm 17.3$ & $62.0-31.0$ \\
\hline & Scomberoides tol (Cuvier, 1832) & $3(0+3)$ & $15.2 \pm 0.3$ & $15.5-14.9$ & $16.9 \pm 0.7$ & $17.6-16.2$ & $47.3 \pm 3.1$ & $50.0-44.0$ \\
\hline & Terapon theraps (Cuvier, 1829) & $5(4+1)$ & $13.4 \pm 0.9$ & $14.8-12.4$ & $14.1 \pm 0.9$ & 15.4-13.2 & $49.6 \pm 13.5$ & $73.0-40.0$ \\
\hline & $\begin{array}{ll}\text { Total } \\
\end{array}$ & \multicolumn{7}{|c|}{$165(86+79)$} \\
\hline
\end{tabular}

$\mathrm{n}=$ total number of sample, $\mathrm{m}=$ male, $\mathrm{f}=$ female, $\mathrm{FL}=$ fork length, $\mathrm{TL}=$ total length, $\mathrm{Wt} .=$ weight, $\pm \mathrm{SD}= \pm$ standard deviation 
Table 2 shows the number of individual fish stomachs examined, the number of individuals from each group with anthropogenic debris, the average number of individual pieces of debris per stomach of fishes (including individuals with no debris), the range of individual pieces of debris per stomach of fishes in each group together with the information on frequency of occurrence. Average and frequency (\%) of occurrence of plastic particles in the stomachs of different types of fishes have been shown in Figure 3.

Table 2. The average number and range of individual pieces of debris per stomach with frequency of occurrence

\begin{tabular}{|c|c|c|c|c|}
\hline Fish species & $\begin{array}{l}\text { Stomach } \\
\text { examined }\end{array}$ & $\begin{array}{c}\text { Stomach } \\
\text { with debris }\end{array}$ & $\begin{array}{c}\text { Number of pieces of } \\
\text { debris/stomach } \\
\text { (average }( \pm \text { SD), Range }\end{array}$ & Frequency (\%) \\
\hline \multicolumn{5}{|c|}{ Demersal fish species $(n=6)$} \\
\hline Alepes apercna & 3 & 2 & $2.0( \pm 2.0), 0-4$ & 67 \\
\hline Dasyatis zugei & 3 & 1 & $0.3( \pm 0.6), 0-1$ & 33 \\
\hline Dendrophysa russellii & 3 & 1 & $0.3( \pm 0.5), 0-1$ & 33 \\
\hline Leiognathus berbis & 8 & 4 & $0.9( \pm 1.0), 0-1$ & 50 \\
\hline Leiognathus fasciatus & 3 & 1 & $1.3( \pm 2.3), 0-4$ & 33 \\
\hline Leiognathus splendens & 10 & 6 & $1.0( \pm 1.1), 0-3$ & 60 \\
\hline \multicolumn{5}{|c|}{ Pelagic fish species $(n=11)$} \\
\hline Alepes melanoptera & 8 & 6 & $1.3( \pm 1.0), 0-3$ & 75 \\
\hline Alepes vari & 3 & 2 & $1.7( \pm 1.5), 0-3$ & 67 \\
\hline Anodontostoma chacunda & 14 & 8 & $2.0( \pm 4.0), 0-15$ & 57 \\
\hline Johnius borneensis & 3 & 2 & $1.0( \pm 1.0), 0-2$ & 67 \\
\hline Johnius carouna & 20 & 17 & $3.8( \pm 3.2), 0-13$ & 85 \\
\hline Opisthopterus tardoore & 3 & 1 & $2.0( \pm 3.5), 0-6$ & 33 \\
\hline Rastrelliger brachysoma & 3 & 1 & $1.0( \pm 1.7), 0-3$ & 33 \\
\hline Sardinella gibbosa & 3 & 1 & $0.3( \pm 0.6), 0-1$ & 33 \\
\hline Sardinella jussieu & 8 & 6 & $1.3( \pm 1.3), 0-4$ & 75 \\
\hline Scomberomorus commerson & 4 & 4 & $4.3( \pm 1.0), 3-5$ & 100 \\
\hline Scomberomorus guttatus & 5 & 3 & $0.6( \pm 0.5), 0-1$ & 60 \\
\hline \multicolumn{5}{|c|}{ Reef-associated fish species $(n=7)$} \\
\hline Alepes kleinii & 4 & 2 & $0.8( \pm 1.0), 0-2$ & 50 \\
\hline Drepane longimana & 3 & 1 & $0.3( \pm 0.6), 0-1$ & 33 \\
\hline Megalaspis cordyla & 29 & 23 & $1.6( \pm 1.2), 0-5$ & 79 \\
\hline Sardinella albella & 14 & 12 & $2.3( \pm 1.8), 0-5$ & 86 \\
\hline Scomberoides tala & 3 & 2 & $0.7( \pm 0.6), 0-2$ & 67 \\
\hline Scomberoides tol & 3 & 2 & $2.2( \pm 2.2), 0-4$ & 67 \\
\hline Terapon theraps & 5 & 2 & $0.8( \pm 1.3), 0-3$ & 40 \\
\hline Total & 165 & \multicolumn{3}{|c|}{$110(66.67 \%$ of total fish $)$} \\
\hline
\end{tabular}




\section{AVERAGE \& FREQUENCY}

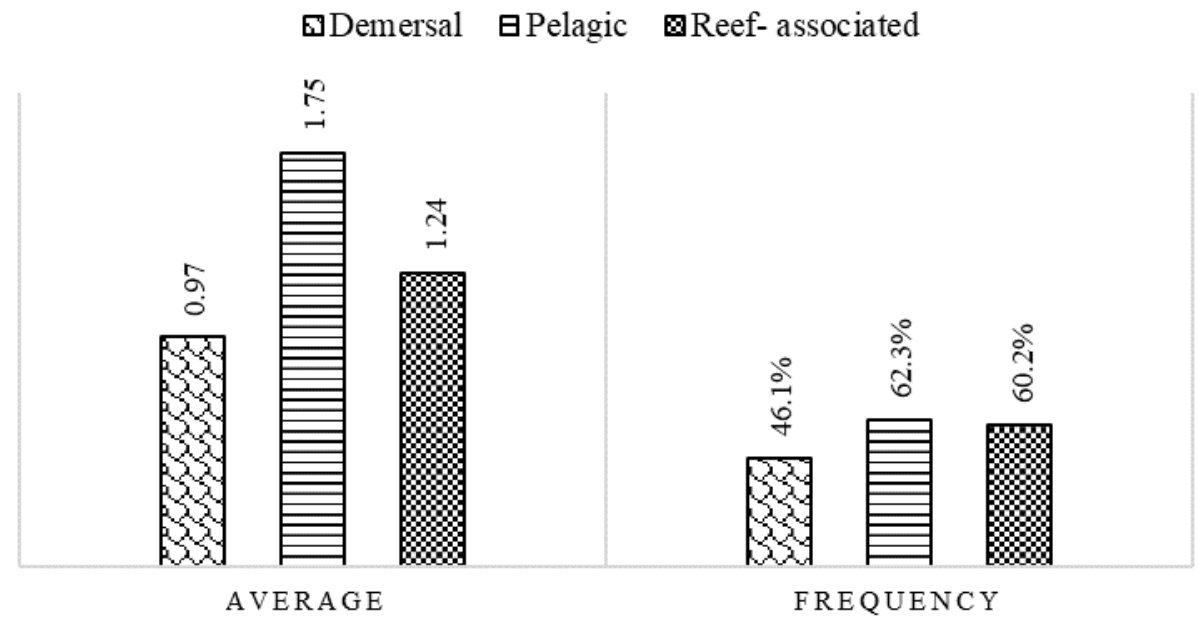

Figure 3. Average (number of particles/ stomach) and frequency (\%) of occurrence of plastic particles in stomach of different types of fishes

In Figure 4a-c, comparison between mouth size of individual fish species and frequency of occurrence of plastic particles in stomach was shown.

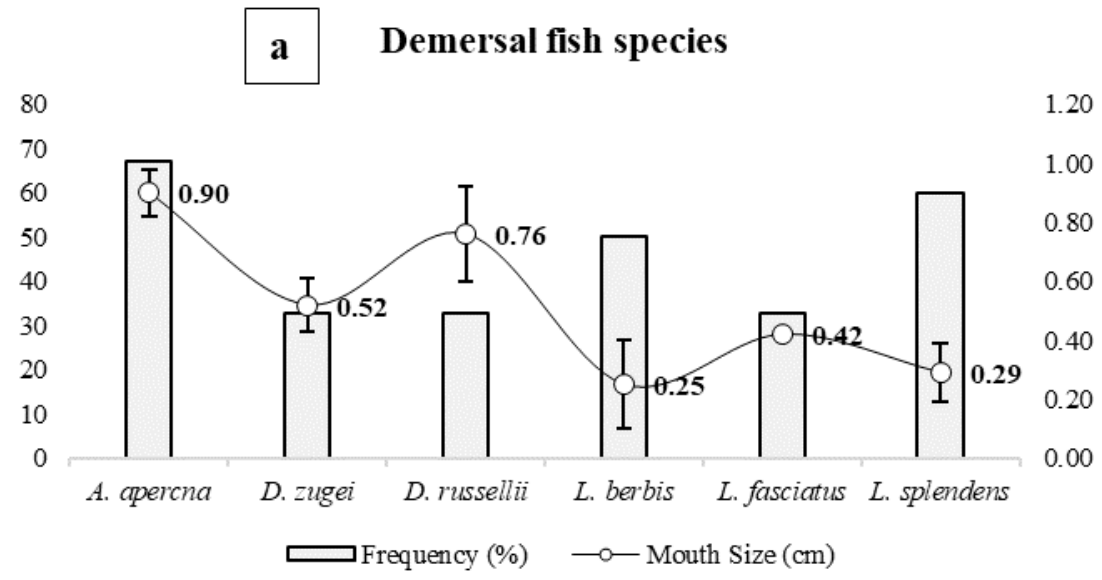

b Pelagic fish species

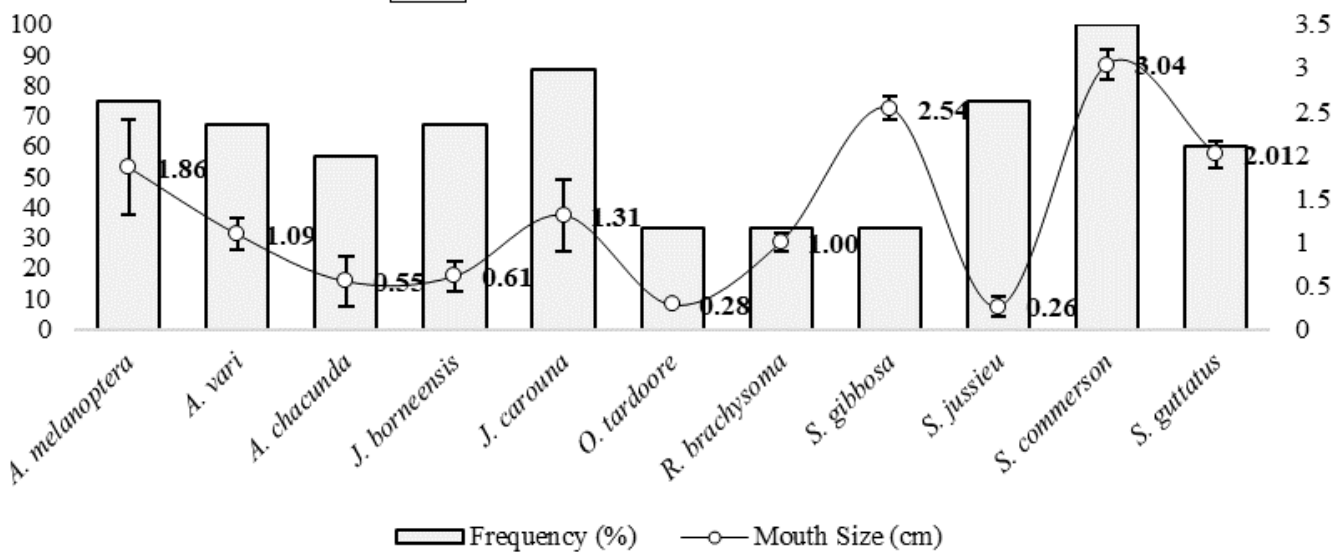




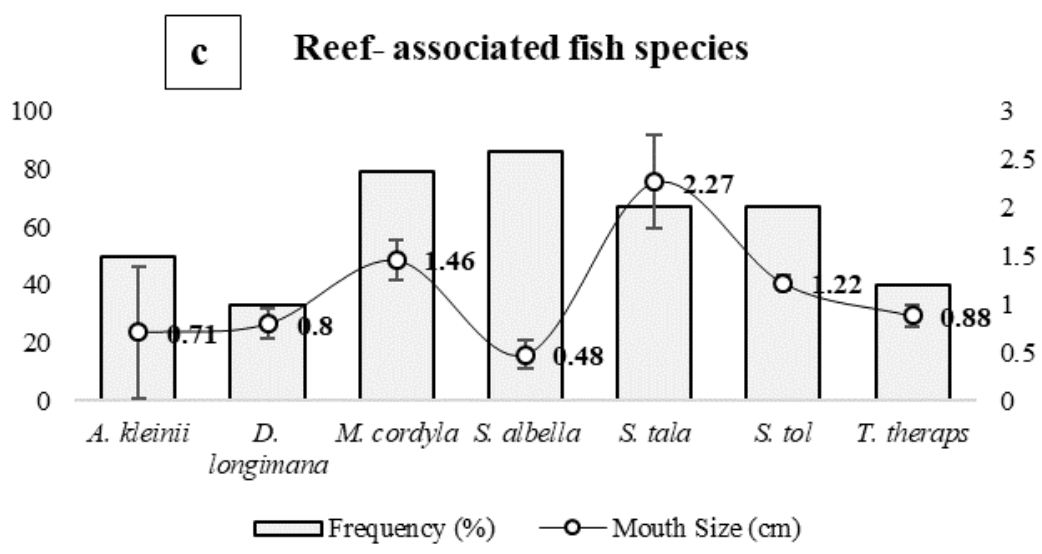

Figure 4. Relevance between frequency (\%) of occurrence of plastic particle in stomach and mouth size $(\mathrm{cm})$ of individual fish species. Error bars represent standard deviations

Plastic particles found in fish stomach had different shapes and colors; Transparent colored plastics were the most dominant color present in the stomachs of examined fishes. Colors, types and size of plastic items found in the stomach contents of fishes were briefly described below (Table 3). Color ranking of plastic particles found in the stomach content of fishes have also been shown in Figure 5.

Table 3. Colors, types and size of plastic particles found in the stomach contents of different fishes

\begin{tabular}{|c|c|c|c|c|}
\hline \multirow[b]{2}{*}{ Fish species } & \multicolumn{4}{|c|}{ Details of plastic particles } \\
\hline & \begin{tabular}{|c|}
$\begin{array}{c}\text { Length range } \\
(\mathrm{mm})\end{array}$ \\
\end{tabular} & \begin{tabular}{|c|}
$\begin{array}{c}\text { Width range } \\
(\mathrm{mm})\end{array}$ \\
\end{tabular} & Color & Type \\
\hline \multicolumn{5}{|c|}{ Demersal fish species $(n=6)$} \\
\hline Alepes apercna & $0.82-4.76$ & $0.03-0.40$ & Transparent, Blue & Fibre, Fragment \\
\hline Dasyatis zugei & 16.67 & 0.16 & Green & Fibre \\
\hline Dendrophysa russellii & 1.34 & 0.02 & Blue & Fibre \\
\hline Leiognathus berbis & $0.53-6.54$ & $0.02-0.23$ & $\begin{array}{c}\text { Transparent, Blue, } \\
\text { Black }\end{array}$ & Fibre \\
\hline Leiognathus fasciatus & $1.60-3.29$ & $0.02-1.33$ & Transparent, Red, Blue & Fibre, Fragment \\
\hline Leiognathus splendens & $0.62-7.41$ & $0.02-0.82$ & \begin{tabular}{|c|} 
Transparent, Blue, \\
Black
\end{tabular} & Fibre, Fragment \\
\hline \multicolumn{5}{|c|}{ Pelagic fish species $(\mathrm{n}=11)$} \\
\hline Alepes melanoptera & $0.52-4.83$ & $0.02-0.51$ & $\begin{array}{c}\text { Transparent, Green, } \\
\text { Black, Red }\end{array}$ & Fibre, Fragment \\
\hline Alepes vari & $2.75-10.55$ & $0.05-0.11$ & $\begin{array}{l}\text { Transparent, Yellow, } \\
\text { Black, Brown }\end{array}$ & Fibre, \\
\hline Anodontostoma chacunda & $0.63-16.36$ & $0.02-2.42$ & $\begin{array}{l}\text { Transparent, Blue, } \\
\text { Red, Black, Brown }\end{array}$ & Fibre, Fragment \\
\hline Johnius borneensis & $2.28-10.55$ & $0.03-0.04$ & Brown, Blue & Fibre \\
\hline Johnius carouna & $0.35-17.16$ & $0.01-1.94$ & $\begin{array}{c}\text { Transparent, Blue, } \\
\text { Brown, Black, Red, } \\
\text { Green }\end{array}$ & Fibre, Fragment \\
\hline Opisthopterus tardoore & $1.18-8.83$ & $0.01-0.04$ & Blue, Black & Fibre \\
\hline Rastrelliger brachysoma & $2.46-5.27$ & $0.04-0.40$ & Transparent & Fibre \\
\hline Sardinella gibbosa & 0.73 & 0.61 & Transparent & Fragment \\
\hline
\end{tabular}




\begin{tabular}{|c|c|c|c|c|}
\hline Sardinella jussieu & $0.75-5.07$ & $0.04-0.96$ & $\begin{array}{c}\text { Transparent, Blue, } \\
\text { Black }\end{array}$ & Fibre, Fragment \\
\hline Scomberomorus commerson & $0.54-8.70$ & $0.02-0.47$ & $\begin{array}{c}\text { Transparent, Black, } \\
\text { Yellow, Red }\end{array}$ & Fibre, Fragment \\
\hline Scomberomorus guttatus & $1.53-2.88$ & $0.03-0.04$ & Transparent, Black & Fibre \\
\hline \multicolumn{5}{|c|}{ Reef-associated fish species $(n=7)$} \\
\hline Alepes kleinii & $0.87-4.41$ & $0.06-2.10$ & Transparent, Black & Fibre, Fragment \\
\hline Drepane longimana & 2.26 & 0.05 & Black & Fibre \\
\hline Megalaspis cordyla & $0.13-15.23$ & $0.01-1.74$ & $\begin{array}{l}\text { Transparent, Blue, } \\
\text { Red, Black, Brown }\end{array}$ & Fibre, Fragment \\
\hline Sardinella albella & $1.29-8.78$ & $0.01-0.81$ & $\begin{array}{l}\text { Transparent, Blue, } \\
\text { Red, Black, Brown }\end{array}$ & Fibre, Fragment \\
\hline Scomberoides tala & $0.83-5.94$ & $0.05-0.68$ & Transparent, Black & Fibre, Fragment \\
\hline Scomberoides tol & $0.69-6.46$ & $0.02-0.09$ & Transparent, Blue, Red & Fibre \\
\hline Terapon theraps & $1.36-3.55$ & $0.02-0.30$ & Transparent, Black & Fibre, Fragment \\
\hline
\end{tabular}

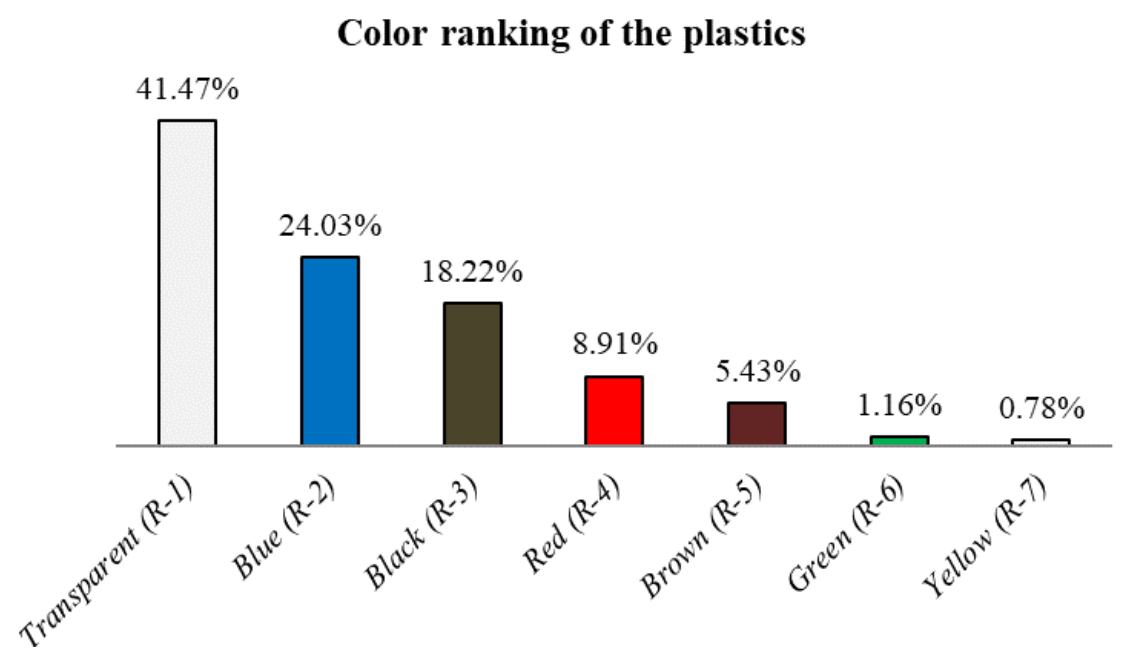

Figure 5. Color ranking of plastic particles found in the stomach contents of fishes $(R$ $1=$ Rank-1)

Relationship between size of plastic litters and different biological features of fishes are given in Figure 6A-C.

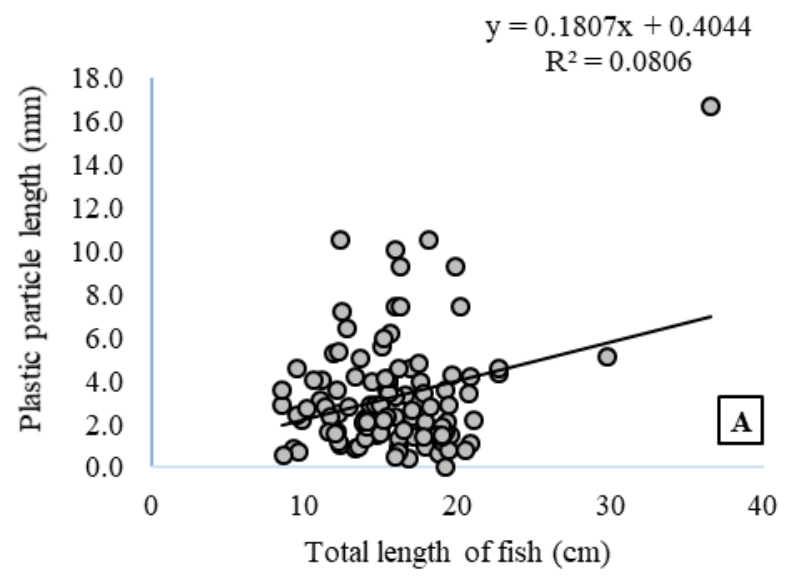



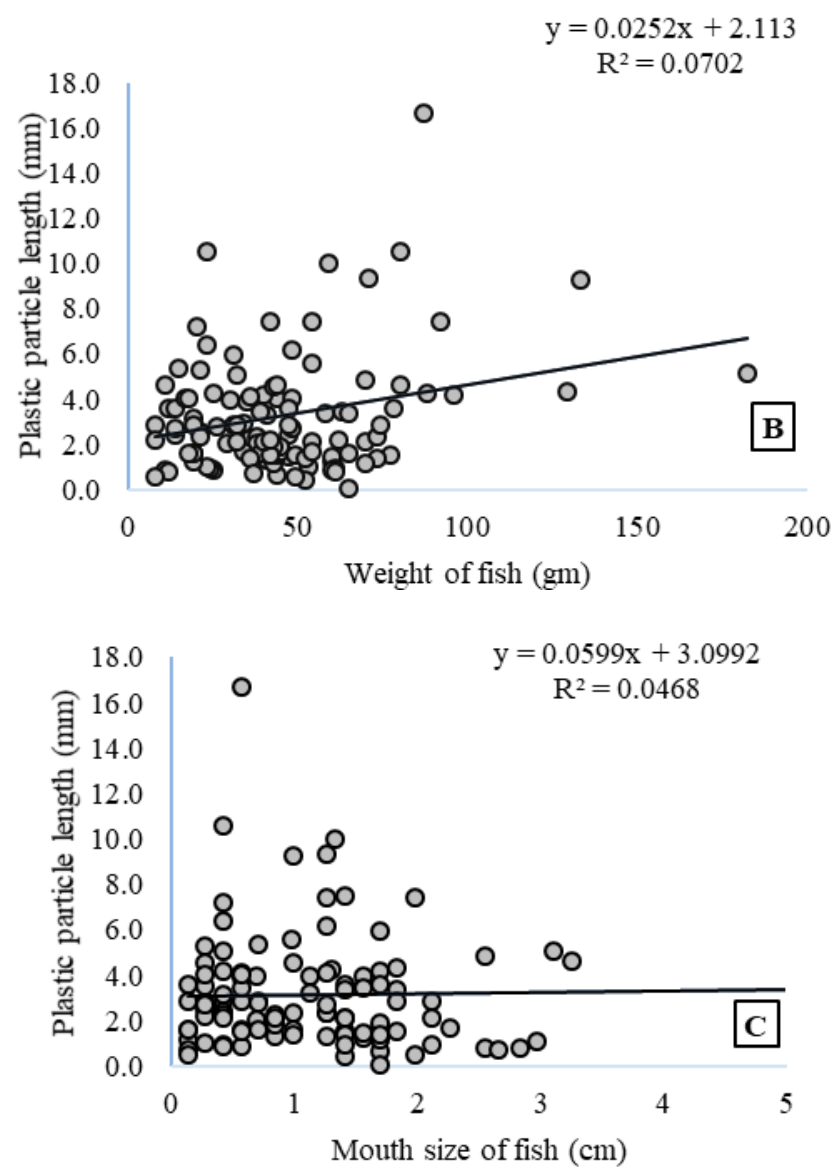

Figure 6. Relationship between size of plastic fragments found in stomach contents and different biological features of fishes. (A) Plastic fragments length VS Total length of fish, (B) Plastic fragments length VS Weight of fish and (C) Plastic fragments length VS Mouth size of fish

Plastic debris found in stomach contents of fishes differed in size in each group of fishes as reported in Figure 7. Microplastics which are less than $5 \mathrm{~mm}$ in size were the most abundant (79.52\%) size group found during the research work (Fig. 7).

\% OF SIZE CATEGORIES OF PLASTICS

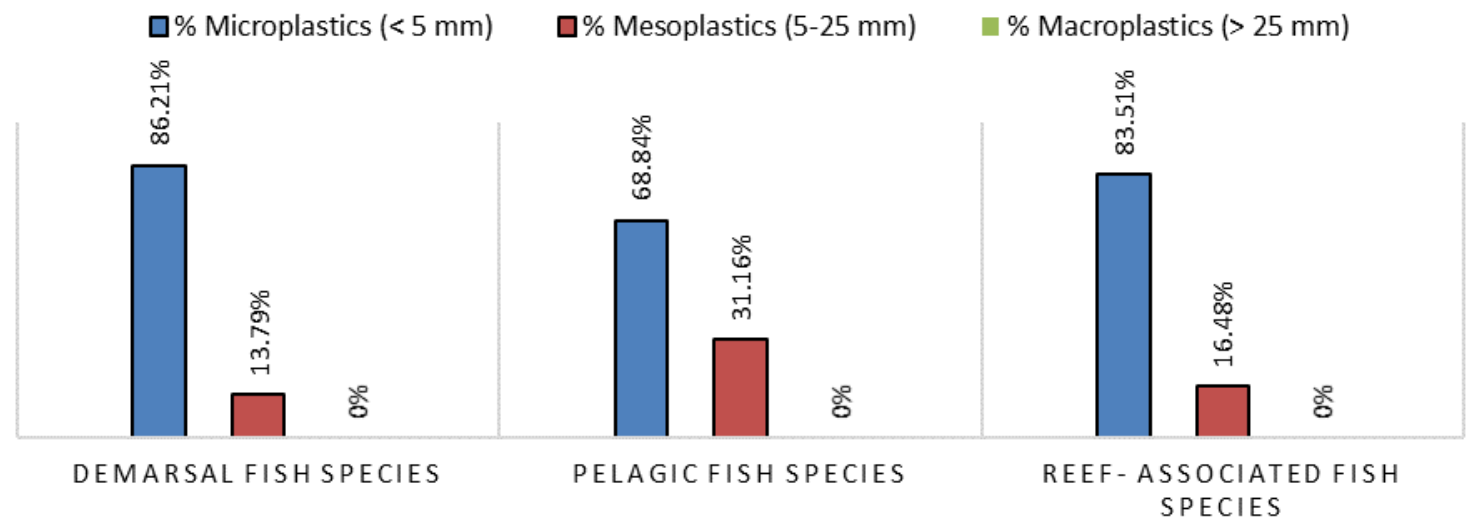

Figure 7. Percentage of size categories of plastic in the stomach contents of each type of fish 
In Figure 8, some illustrations of plastic debris found in the stomach contents of fishes are shown.

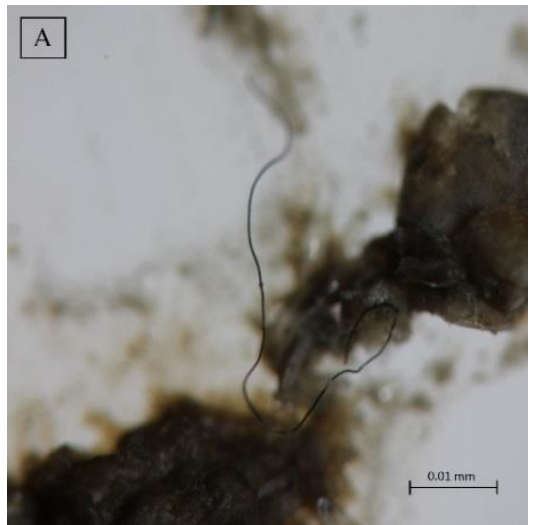

Figure 8. Photographs of plastic debris found in the stomach content of fishes. Net fibre $(A, B)$ and plastic fragment $(C)$

\section{Discussion}

Recent investigations (Fossi et al., 2012) revealed data on the effect of microplastics on massive filter-feeding creatures such as baleen whales and sharks in the Mediterranean sea, which can possibly devour microplastic offal. No data has been reported on microplastic ingestion by fishes from lower Southern Thailand. This study provided the first published record of plastic polymers in the stomach contents of some commercially important fishes from the lower Gulf of Thailand (Fig. 1). Size and weight of the examined fishes ranges from 8.5 to $37.1 \mathrm{~cm}$ and 8 to $133 \mathrm{~g}$. respectively (Table 1). Of the 165 fish stomachs examined, 66.67\% contained plastic items. Particularly, this consisted of 15 demersal individual fishes (50\%), 51 pelagic individual fishes $(68.92 \%)$ and 44 reefs- associated individual fishes $(72.13 \%)$ containing some kinds of plastic matters (Table 2). The average occurrence of plastic particles in the pelagic fish (1.75 particles/ stomach) was higher than that of demarsal fish (0.97 particles/ stomach) by approximately two times (Fig. 3). This probably implied that the plastic contamination in the study area was possibly related to the density of the plastic particles. HDPE (high density polyethylene), LDPE (low density polyethylene), and PP (polypropylene) which make up containers and plastic bags for example do float, as their density is less than that water. Higher density plastics such as PET (polyethylene terephthalate), PVC (polyvinyl chloride), and PS (polystyrene solid), do sink. The second probable explanation was that the pelagic fishes in the study area had more herbivorous (plankton feeding) fishes than carnivorous fishes as compared to the demarsal fishes and therefore was responsible for the higher occurrence of plastic pieces in the pelagic fishes than that of the demersal ones.

Since this is the first study on plastic ingestion by fishes from the lower Gulf of Thailand, there is no other study in Thailand to compare with. However, there were some other findings from different places around the world. Possatto et al. (2011) who perceptibly recorded ingested plastic from fishing nets in $23 \%$ of the three species of catfish (C. spixii, C. agassizii and S. herzbergii) found in the estuary of River Goiás in Northeast Brazil, but lower in comparison with a study by Boerger et al. (2010), who visually acknowledged plastic in $35 \%$ of 670 individuals of five mesopelagic and one 
epipelagic fish species caught with a manta trawl $(0.33 \mu \mathrm{m}$ mesh size $)$ in the North Pacific Gyre. Furthermore, Lusher et al. (2013), who informed 36.5\% of the 504 gastrointestinal tracts from 10 species of fish from the English Channel to have plastic contents. Since Thailand was one of the five countries who dumped more plastic $(60 \%)$ into the oceans than the rest of the world combined (GlobalPost, 2016), the result from the current study showed alarmingly high percentage $(66.67 \%)$ of plastic ingestion by fishes.

This current investigation indicated that the pelagic fish species had more plastic substances in their gut content in average, which was 1.75 plastic litter/stomach (Fig. 3). Contrarily, demersal fish species had less plastic items (0.97 plastic litter/ stomach) than other classes of fishes (Fig. 3). Besides, Figure 2 represents the frequency (\%) of occurrence of plastic particles in the stomach contents of different classes of fishes. Pelagic fish species showed the highest (62.3\%) frequency of occurrence of plastic items, whereas, demersal fishes showed the lowest $(46.1 \%)$ frequency of occurrence of plastic matters in the stomach contents of fishes (Fig. 3). Similar study was done by Romeo et al. (2015), who worked on large pelagic fishes (Xiphias gladius, Thunnus thynnus and Thunnus alalunga) in the Mediterranean Sea and found $18.18 \%$ of the fish stomach contained some kinds of plastic matters, which was lower than those of the current study. The ingestion of microplastics by mesopelagic fish was also reported in the Pacific Ocean (Boerger et al., 2010; Davison and Asch, 2011). Since most of plastic particles tend to float on the surface level of the water because of their density and structural behavior, pelagic fishes ingest the plastic particles erroneously as food. Sometimes filter-feeding fish species ingest plastic matters while filtering the water by their gill and gulping during lack of oxygen situation. On the other hand, reef-associated fish species showed around 60\% frequency of occurrence (Fig. 3). In addition, reefassociate species are also threatened because of plastic pollution. Some plastic particles with comparatively high density settle down on the reef bed and are erroneously taken by reef-associated fishes. Plastic litters (macro to microplastics) can also be ingested through predation action, in particular, when predatory fish catch their small prey aggregated in schools. This kind of feeding comportment may enhance the feasibility of ingesting plastic debris together with the prey (Romeo et al., 2015).

In this current study, relevance between mouth size $(\mathrm{cm})$ of the individual fish and frequency $(\%)$ of occurrence of plastic particle in stomach content was also been investigated (Fig. 4). Nevertheless, comprehensively there was no relativity found between frequency of occurrence of plastic matters and mouth size of individual fishes excluding some species such as A. apercna, D. zugei, R. brachysoma, S. commerson, $S$. guttatus, $D$. longimana and $S$. tala. These species indicated moderately positive relevance between frequency of occurrence and mouth size of fish (Fig. 4). Differently, L. berbis, L. splendens, A. chacunda, J. borneensis, S. jussieu and S. albella revealed comparatively negative relativity (Fig. 4). Since this is the inceptive search on this sort of relativity, there is no convenient investigation to correlate with.

The plastic items found in the stomach contents of the samples ranged from $0.13 \mathrm{~mm}$ to $17.16 \mathrm{~mm}$ in length and width ranged from 0.01-2.42 $\mathrm{mm}$ (Table 3). Though the plastic items obtained were either fibre type or fragment type, most of them were fibre from fish nets (Table 3). These plastic litters had different shapes and different colors. Transparent $(41.47 \%)$ colored plastic items were the most dominant color of plastics found during this investigation (Fig. 5). Differently, Yellow (0.78\%) colored plastics were the smallest group of plastic litters obtained in the current study (Fig. 5). Since 
transparent color is nearly illusive to see in the water, aquatic organisms especially fishes erroneously take this sort of plastic litters while gulping, filter-feeding and consuming food. Sometimes, fishes unintentionally ingest plastic litters as a live food as well. Size of the plastic items found in the gut contents were also been categorized. Microplastics $(<5 \mathrm{~mm}$ ) were the most abundant (79.52\%) size group of plastic items obtained from the stomach content of fishes during this investigation and the rest of them $(20.48 \%)$ were mesoplastics $(5-25 \mathrm{~mm})$ In particular, demersal and reef-associated fish species showed more or less similar amount of microplastics which are $86.21 \%$ and $83.51 \%$ respectively. Since the sizes of the fish individuals were small, there was no macroplastic (>25 mm) found during the investigation (Fig. 6). One of the recent study also showed the dominancy of transparent colored plastic items in the stomach contents of fishes done by Romeo et al. (2015), who also found microplastic as the most abundant size group of plastics in fish gut of albacore and bluefin tuna. Furthermore, there are a number of more scientists who also found microplastic particles in fish gastrointestinal tract (Lusher et al., 2013; Murphy et al., 2017; Phillips and Bonner, 2015; Tanaka and Takada, 2016). In the current investigation, for the first time, relevance between size of plastic litters and different biological features of fishes such as total length, weight and mouth size were investigated (Fig. 6). The scatterplots (Fig. 6) shows the points fall randomly on the plot, which indicates that there is no linear relationship between the variables $(\mathrm{p}<0.05)$. It means that there has no discernable increasing or decreasing linear pattern in those graphs (Fig. 6). As expected, the sizes of microplastic particles $(<5 \mathrm{~mm})$ were so small until all sizes of fishes even the small ones with small mouths could swallow them. Big carnivorous fish could contaminate with microplastic by eating the microplastic contaminated herbivorous fish, whereas the big plankton feeding fish could intake microplastic particles by eating plankton mingled with microplastic debris. However, more detailed information and investigations are needed to determine this sort of relevance. Results of the current study emphasize the pervasive existence of plastics in the lower Gulf of Thailand. Moreover, the high frequencies of micro and mesoplastics in the marine fishes from the lower Gulf of Thailand represent a further warning signal for marine conservation as well as for the soundness of human health.

\section{Conclusions and recommendations}

The accession of the microplastics as well as other sized plastic litters in commercially important marine fishes suggestively reveals the anthropogenic stress on the fishery and marine food security in the lower Gulf of Thailand. Health perils are feasible when people consume these defiled marine organisms. These fundamental findings signify a vital initial phase in exploring some ecotoxicological aspects such as the possible effects associated to the transmission of contaminants on human health and the assessment of the existence and effect of plastic debris on other types of marine organisms. Moreover, effective management programs in the study area and contiguous areas for the plastic pollution are immediately required. Wherefore, linked to the high consumption of these species in the Gulf of Thailand, this topic necessitates profounder investigation in the futurity. In addition, it is definitely recommended that microplastic contamination in marine organisms and their food chain in other adjacent provinces should be explored to make sure the safety circumstances of environment and human health. Moreover, this is an elementary research work which need further in detail investigations. 
Acknowledgements. The authors would like to thank Thailand's Education Hub for ASEAN Countries (TEH-AC) Scholarship and Graduate School, Prince of Songkla University for funding and associating this research work. We also gratefully thank Assist. Prof. Dr. Jarunee Chaiyvareesajja for her helps to collect and identify fish samples. Special thanks go to the Coastal Oceanography and Climate Change Research Center, MACORIN, PSU as well as Marine and Coastal Resources Research and Development Center Lower Gulf of Thailand (MCRRDL), Department of Marine and Coastal Resources for their kind assistance and support throughout the research work.

\section{REFERENCES}

[1] Barnes, D. K. A., Galgani, F., Thompson, R. C., Barlaz, M. (2009): Accumulation and fragmentation of plastic debris in global environments. - Philosophical Transactions of the Royal Society B: Biological Sciences 364: 985-1998.

[2] Boerger, C. M., Lattin, G. L., Moore, S. L., Moore, C. J. (2010): Plastic ingestion by planktivorous fishes in the North Pacific Central Gyre. - Marine Pollution Bulletin 60: 2275-2278.

[3] Browne, M. A. R. T. (2010): Spatial patterns of plastic debris along estuarine shorelines. - Environ. Sci. Technol 44: 3404-3409.

[4] Chiemchaisri, C., Juanga, J. P., Visvanathan, C. (2007): Municipal solid waste management in Thailand and disposal emission inventory. - Environmental Monitoring and Assessment 135: 13-20.

[5] Claessens, M., Van Cauwenberghe, L., Vandegehuchte, M. B., Janssen, C. R. (2013): New techniques for the detection of microplastics in sediments and field collected organisms. - Marine Pollution Bulletin 70: 227-233.

[6] Cole, M., Lindeque, P., Halsband, C., Galloway, T. S. (2011): Microplastics as contaminants in the marine environment: A review. - Marine Pollution Bulletin 62: 2588-2597.

[7] Davison, P., Asch, R. G. (2011): Plastic ingestion by mesopelagic fishes in the North Pacific Subtropical Gyre. - Marine Ecology Progress Series 432: 173-180.

[8] Derraik, J. G. B. (2002): The pollution of the marine environment by plastic debris: A review. - Marine Pollution Bulletin 44: 842-852.

[9] Deudero, S., Alomar, C. (2014): Revising Interactions of Plastics with Marine Biota: Evidence from the Mediterranean. Marine Litter in the Mediterranean and Black Seas. In: Briand, F. (ed.) CIESM Workshop Monograph n 46. CIESM Publisher, Monaco, pp. 79-85.

[10] De Witte, B., Devriese, L., Bekaert, K., Hoffman, S., Vandermeersch, G., Cooreman, K., Robbens, J. (2014): Quality assessment of the blue mussel (Mytilus edulis): Comparison between commercial and wild types. - Marine Pollution Bulletin 85: 146-155.

[11] Dias, B. F. D. S., Lovejoy, T. E. (2012): Impacts of marine debris on biodiversity: current status and potential solutions. - CBD Technical Series 67: 11-26.

[12] Eriksen, M., Lebreton, L. C. M., Carson, H. S., Thiel, M., Moore, C. J., Borerro, J. C., Galgani, F., Ryan, P. G., Reisser, J. (2014): Plastic pollution in the world's oceans: more than 5 trillion plastic pieces weighing over 250,000 tons afloat at sea. - PLoS ONE 9: 115.

[13] Fendall, L. S., Sewell, M. A. (2009): Contributing to marine pollution by washing your face: Microplastics in facial cleansers. - Marine Pollution Bulletin 58: 1225-1228.

[14] Fossi, M. C., Panti, C., Guerranti, C., Coppola, D., Giannetti, M., Marsili, L., Minutoli, R. (2012): Are baleen whales exposed to the threat of microplastics? A case study of the Mediterranean fin whale (Balaenoptera physalus). - Marine Pollution Bulletin 64: 23742379.

[15] Fossi, M. C., Coppola, D., Baini, M., Giannetti, M., Guerranti, C., Marsili, L., Panti, C., Sabata, E., Clò, S. (2014): Large filter feeding marine organisms as indicators of 
microplastic in the pelagic environment: the case studies of the Mediterranean basking shark (Cetorhinus maximus) and fin whale (Balaenoptera physalus). - Marine Environmental Research 100: 17-24.

[16] Froese, R., Pauly, D. (2017): FishBase. World Wide Web electronic publication. www.fishbase.org, version (01/2017).

[17] Galgani, F., Hanke, G., Werner, S., Oosterbaan, L., Nilsson, P., Fleet, D., Kinsey, S., Thompson, R. C., VanFraneker, J., Vlachogianni, T., Scoullos, M., Mira Veiga, J., Palatinus, A., Matiddi, M., Maes, T., Korpinen, S., Budziak, A., Leslie, H., Gago, J., Liebezeit, G. (2013): Monitoring Guidance for Marine Litter in European Seas. - JRC Scientific and Policy Reports. Report EUR 26113 EN.

[18] Gall, S. C., Thompson, R. C. (2015): The impact of debris on marine life. - Marine Pollution Bulletin 92: 170-179.

[19] GlobalPost (2016): 5 countries dump more plastic into the oceans than the rest of the world combined. - Global Post, 13 January.

[20] Gregory, M. R. (2009): Environmental implications of plastic debris in marine settingsentanglement, ingestion, smothering, hangers-on, hitch-hiking and alien invasions. Philosophical Transactions of the Royal Society B: Biological Sciences 364: 2013-2025.

[21] Imhof, H. K., Ivleva, N. P., Schmid, J., Niessner, R., Laforsch, C. (2013): Contamination of beach sediments of a subalpine lake with microplastic particles. - Current Biology 23: R867-R868.

[22] Ivar Do Sul, J. A., Costa, M. F. (2014): The present and future of microplastic pollution in the marine environment. - Environmental Pollution 185: 352-364.

[23] Jambeck, J. R., Geyer, R., Wilcox, C., Siegler, T. R., Perryman, M., Andrady, A., Narayan, R., Law, K. L. (2015): Plastic waste inputs from land into the ocean. - Science 347: 768-771.

[24] Kaosol, T. (2009): Sustainable solutions for municipal solid waste management in Thailand. - Engineering 60: 665-670.

[25] Lazar, B., Gračan, R. (2011): Ingestion of marine debris by loggerhead sea turtles, Caretta caretta, in the Adriatic Sea. - Marine Pollution Bulletin 62: 43-47.

[26] Lippiatt, S., Opfer, S., Arthur, C. (2013): Marine Debris Monitoring and Assessment. NOAA Technical Memorandum NOS-OR\&R-46.

[27] Lusher, A. L., McHugh, M., Thompson, R. C. (2013): Occurrence of microplastics in the gastrointestinal tract of pelagic and demersal fish from the English Channel. - Marine Pollution Bulletin 67: 94-99.

[28] Moore, C. J. (2008): Synthetic polymers in the marine environment: A rapidly increasing, long-term threat. - Environmental Research 108: 131-139.

[29] Moore, C. J., Moore, S. L., Leecaster, M. K., Weisberg, S. B. (2001): A comparison of plastic and plankton in the North Pacific Central Gyre. - Marine Pollution Bulletin 42: 1297-1300.

[30] Murray, F., Cowie, P. R. (2011): Plastic contamination in the decapod crustacean Nephrops norvegicus (Linnaeus, 1758). - Marine Pollution Bulletin 62: 1207-1217.

[31] Murphy, F., Russell, M., Ewins, C., Quinn, B. (2017): The uptake of macroplastic and microplastic by demersal and pelagic fish in the Northeast Atlantic around Scotland. Marine Pollution Bulletin 122: 353-359.

[32] Phillips, M. B., Bonner, T. H. (2015): Occurrence and amount of microplastic ingested by fishes in watersheds of the Gulf of Mexico. - Marine Pollution Bulletin 100: 264-269.

[33] PlasticsEurope (2016): Plastics - The Facts 2016. - www.plasticseurope.de/informations.

[34] Possatto, F. E., Barletta, M., Costa, M. F., Ivar do Sul, J. A., Dantas, D. V. (2011): Plastic debris ingestion by marine catfish: An unexpected fisheries impact. - Marine Pollution Bulletin 62: 1098-1102.

[35] R Core Team (2015): R: A language and Environment for Statistical Computing. - R Foundation for Statistical Computing, Vienna, Austria. http://www.R-project.org/. 
[36] Rios, L. M., Jones, P. R., Moore, C., Narayan, U. V. (2010): Quantitation of persistent organic pollutants adsorbed on plastic debris from the Northern Pacific Gyre's "eastern garbage patch." - Journal of Environmental Monitoring 12: 2226-2236.

[37] Rocha-Santos, T., Duarte, A. C. (2015): A critical overview of the analytical approaches to the occurrence, the fate and the behavior of microplastics in the environment. - Trends in Analytical Chemistry 65: 47-53.

[38] Romeo, T., Pietro, B., Pedà, C., Consoli, P., Andaloro, F., Fossi, M. C. (2015): First evidence of presence of plastic debris in stomach of large pelagic fish in the Mediterranean Sea. - Marine Pollution Bulletin 95: 358-361.

[39] SEAFDEC (2014): List of Aquatic Animals and Plants in Southeast Asia. - Southeast Asian Fisheries Development Center, Thailand.

[40] Shirota, A. (1970): Studies on the mouth size of fish larvae. - Bulletin of the Japanese Society of Scientific Fisheries 36: 353-368.

[41] Song, Y. K., Sang, H. H., Mi, J., Gi, M. H., Won, J. S. (2015): Occurrence and distribution of microplastics in the sea surface microlayer in Jinhae Bay, South Korea. Archives of Environmental Contamination and Toxicology 69: 279-87.

[42] Talwar, P. K., Jhingran, A. G. (1991): Inland Fishes of India and Adjacent Countries. IBH publishing, New Delhi.

[43] Tanaka, K., Takada, H. (2016): Microplastic fragments and microbeads in digestive tracts of planktivorous fish from urban coastal waters. - Scientific Reports 6: 1-8.

[44] Thompson, R. C., Moore, C. J., vom Saal, F. S., Swan, S. H. (2009): Plastics, the environment and human health: current consensus and future trends. - Philosophical Transactions of the Royal Society B: Biological Sciences 364: 2153-2166.

[45] Van Cauwenberghe, L., Janssen, C. R. (2014): Microplastics in bivalves cultured for human consumption. - Environmental Pollution 193: 65-70.

[46] Van Franeker, J. A., Blaize, C., Danielsen, J., Fairclough, K., Gollan, J., Guse, N., Hansen, P. -L., Heubeck, M., Jensen, J. -K., Le Guillou, G., Olsen, B., Olsen, K. -O., Pedersen, J., Stienen, E. W. M., Turner, D. M. (2011): Monitoring plastic ingestion by the northern fulmar Fulmarus glacialis in the North Sea. - Environmental Pollution 159: 2609-2615.

[47] Woodall, L. C., Sanchez-Vidal, A., Canals, M., Paterson, G. L. J., Coppock, R., Sleight, V., Calafat, A., Rogers, A. D., Narayanaswamy, B. E., Thompson, R. C. (2014): The deep sea is a major sink for microplastic debris. - Royal Society Open Science 1: 140317140317. 